\title{
Use bioregulators in cluster ToV (Salanum lycopersicum L.)
}

\section{Uso de biorreguladores en tomate (Salanum lycopersicum L.) de racimo ToV}

\author{
CALDERÓN-RUIZ, Alberto $^{1} \dagger$, MARTÍNEZ-CAMACHO, Adriana Paola ${ }^{1}$, ESPINOZA-ZAMORA, \\ Jesús $^{1}$ and RIVERA-ARREDONDO, Marisa ${ }^{1}$
}

${ }^{1}$ Universidad Tecnológica del Suroeste de Guanajuato, Carr. Valle-Huanímaro km 1.2 Valle de Santiago, Gto.

ID $1^{\text {st }}$ Author: Alberto, Calderón-Ruiz / ORC ID: 0000-0002-1721-2953, CVU CONACYT ID: 167136

ID $1^{\text {st }}$ Coauthor: Adriana Paola, Martínez-Camacho / ORC ID: 0000-0003-1970-4633, CVU CONACYT ID: 714204

ID $2^{\text {nd }}$ Coauthor: Jesús, Espinoza-Zamora / ORC ID: 0000-0002-4760-2020, CVU CONACYT ID: 44626

ID $3^{\text {rd }}$ Coauthor: Marisa, Rivera-Arredondo / ORC ID: 0000-0001-5306-2027, CVU CONACYT ID: 388201

DOI: $10.35429 / J N A S .2020 .20 .7 .27 .31$

Received March 21, 2020; Accepted June 30, 2020

\begin{abstract}
Tomato (Solanum lycopersicum L.), is one of the most important vegetables that supports food and nutritional security. One of the various forms that is offered is in cluster, also known as ToV, being one of the specialties of the tomato ball. The disadvantage is the visual quality (the homogeneous color) that determines the level of consumer acceptance and the foreign market, as well as the consumption time. Due to this, the effect of two spray techniques (mopping and touch) in postharvest on the ToV fruits grown in the greenhouse was evaluated. This to favor the homogeneity of color; using bioregulators: A) 2cloroethyl phosphonic acid y B) $\mathrm{K}_{2} \mathrm{O} 20 \%$. in three concentrations $\left[\mathrm{A}\left(\mathrm{T}_{1}=7.2 \mathrm{ppm}, \mathrm{T}_{2}=12 \mathrm{ppm}\right.\right.$ y $\mathrm{T}_{3}=120$ ppm, $\mathrm{T}_{4}=$ control $\left.\mathrm{H}_{2} \mathrm{O}\right)$; $\mathrm{B}\left(\mathrm{T}_{1}=66 \mathrm{ppm}, \mathrm{T}_{2}=550 \mathrm{ppm}, \mathrm{T}_{3}=\right.$ $715 \mathrm{ppm}, \mathrm{T}_{4}=$ control $\mathrm{H}_{2} \mathrm{O}$ )] under a complete randomized design with three repetitions to two observations (initial final) during seven days. The results were subjected to post hoc comparisons, for which the weight variable in both bioregulators did not show statistical effect; however, in the color variable, the spraying techniques showed statistical differences with respect to the control. Therefore, it is concluded that the use of bioregulators in post-harvest is a solution to the color homogeneity of the ToV tomato.
\end{abstract}

Solanum lycopersicum L., Post-harvest bioregulators, Application techniques

\begin{abstract}
Resumen
Tomate o tomatera (Solanum lycopersicum L.), es una de las hortalizas más importantes que da sustento a la seguridad alimentaria y nutricional. Una de las diversas formas que es ofertado es en racimo. También conocido como ToV, siendo una de las especialidades del tomate bola. La desventaja es la calidad visual (el color homogéneo) que determina el nivel de aceptación del consumidor y el mercado extranjero, al igual que el tiempo de consumo. Debido a esto, se evaluó el efecto de dos técnicas de aspersión (mopeo y toque) en postcosecha sobre los frutos ToV cultivados en invernadero. Esto para favorecer la homogeniedad de color; mediante los biorreguladores: A) Âcido 2-cloroetil fosfónico y B) $\mathrm{K}_{2} \mathrm{O}$ $20 \%$. A tres concentraciones: $\left[\mathrm{A}\left(\mathrm{T}_{1}=7.2 \mathrm{ppm}, \mathrm{T}_{2}=12 \mathrm{ppm}\right.\right.$ y $\mathrm{T}_{3}=120 \mathrm{ppm}, \mathrm{T}_{4}=$ control $\left.\mathrm{H}_{2} \mathrm{O}\right)$; $\mathrm{B}\left(\mathrm{T}_{1}=66 \mathrm{ppm}, \mathrm{T}_{2}=\right.$ $550 \mathrm{ppm}, \mathrm{T}_{3}=715 \mathrm{ppm}, \mathrm{T}_{4}=$ testigo $\mathrm{H}_{2} \mathrm{O}$ )], bajo un diseño completo al azar con tres repeticiones a dos observaciones (inicial- final) durante siete días. Los resultados se sometieron a comparaciones post hoc, para los cuales la variable peso en ambos biorreguladores no mostro efecto estadístico; sin embargo, en la variable color, las técnicas de aspersión mostraron diferencias estadísticas con respecto al testigo. Por lo que, se concluye que el uso de biorreguladores en postcosecha es una solución a la homogeniedad de color del tomate ToV.
\end{abstract}

Solanum lycopersicum L., Biorreguladores en postcosecha, Técnicas de aplicación

Citation: CALDERÓN-RUIZ, Alberto, MARTíNEZ-CAMACHO, Adriana Paola, ESPINOZA-ZAMORA, Jesús and RIVERA-ARREDONDO, Marisa. Use bioregulators in cluster ToV (Salanum lycopersicum L.). Journal of Natural and Agricultural Sciences. 2020, 7-20: 27-31

\footnotetext{
*Correspondence to Author (acalderonr@utsoe.edu.mx)
}

$\dagger$ Researcher contributing first author 


\section{Introduction}

Tomato (S. lycopersicum L.) is one of the most important fruit crops in the food industry (Navarro-González, and Periago, 2016), whose main use is the preparation of traditional dishes, preparation of sauces and processed products (pasta, juice, dehydrated, among others (Leyva and Pérez, 2015). Currently, vitamins such as $\mathrm{B} 1, \mathrm{~B} 2, \mathrm{~B} 5, \mathrm{E}$ and $\mathrm{C}$ have been considered as an important source; also carbohydrates, phosphorus $(\mathrm{P})$, potassium $(\mathrm{K})$ and magnesium (Mg) (Palomo, 2010), in addition to lycopene, flavonoids, flavones and total phenolic compounds, whose consumption is related to their antimutagenic potential and anticancer properties (Luna and Delgado, 2014).

In Mexico it is one of the main vegetables that is exported, the high demand has diversified the obtaining of this fruit and to satisfy the demands, there is a great segmentation of the market and therefore a wide range of types and varieties of tomato: round or round, saladette or roma, cluster. Flu or grape, cherry, cocktail, pear and heirloom (Intagri, 2017).

The cluster tomato, also known as ToV is a specialty of ball tomatoes, which are characterized by the fact that they are harvested in bunches and the commercial presentation is in clusters of 4 or 5 fruits. Among the most important quality parameters of TOV tomato clusters are: (1) well colored, (2) bright (without marks or immature green spots), (3) uniform shape, (4) texture or strong firmness (5) taste and (6) clean and (7) free from external defects. One of the parameters that influences the marketing of Tov tomato is the visual quality (the homogeneous color), which determines the level of acceptance of the consumer and the foreign market, as well as the time of consumption this interacts with it.

There are different agronomic practices that different physiological activities canbe controlled, such as: vegetative growth control, size increase and fruit set, among others. (Ramírez et al., 2012). The ripening of fruits is one of the processes that receives the most attention for postharvest in tomato. The use of plant hormones is an agronomic practice that contributes to the control of physiological activities.
On the other hand, there are compounds (bioregulators) that in low concentrations promote, inhibit or modify the morphophysiological process associated with their use (Cuesta and Mondaca, 2014). Ethephon (2-chloroethyl phosphonic acid), is a phytoregulator precursor of ethylene, a plant hormone that regulates growth (Crisosto et al., 2010). Ethylene regulates the change in composition and structures during fruit ripening, an increase in carotenoids, which in the case of tomato helps to homogenize the color, it is currently the most used (Chandrika et al., 2003). On the other hand, the use of nutrients exogenously has the synergy to help physiological processes, for example, potassium (K) and boron B). These have an effect on the translocation of sugars and carbohydrates, nitrogen $(\mathrm{N})$ metabolisms, protein synthesis, enzyme activation, key processes in color (Martínez, 2017).

\section{Materials and methods}

\section{Vegetal material}

The Maxesa variety (Enza Zaden), organic ToV cluster tomato, was used. The experiment was carried out in a greenhouse whose location is at $20^{\circ} 28^{\prime} 56.0$ "N $101^{\circ} 10^{\prime} 59.6^{\prime} \mathrm{W}$.

\section{Applied bioregulators}

Two products were used

A) 2-chloroethyl phosphonic acid Using three different concentrations:

$\mathrm{T} 1=7.2 \mathrm{ppm}$

$\mathrm{T} 2=12 \mathrm{ppm}$

$\mathrm{T} 3=120 \mathrm{ppm}$

$\mathrm{T} 4=\mathrm{H} 2 \mathrm{O}$ Control)

B) $\quad \mathrm{K}_{2} \mathrm{O} 20 \%$.

Using three different concentrations

$\mathrm{T}_{1}=66 \mathrm{ppm}$,

$\mathrm{T}_{2}=550 \mathrm{ppm}$,

$\mathrm{T}_{3}=715 \mathrm{ppm}$,

$\mathrm{T}_{4}=$ control $\mathrm{H}_{2} \mathrm{O}$ )

\section{Experimental design}

The experiment was established under a complete randomized design with three repetitions of two observations (initial-final) for seven days. Through two application techniques of bioregulators. 
1)

Moping: which consists of covering the cluster tomato with the product using a towel which is immersed in the treatment and rubbed on the tomatoes.

2) Touch: it consists of applying the dilution in the lower part of the calyx and the stylar region of the tomato only.

Each sample consisted of three ToV cluster tomatoes, placed in low-density polypropylene bags, with a sanitizing solution of paraacetic acid at a concentration of $80 \mathrm{ppm}$. and were placed in a cold chamber, whose conditions were relative humidity $(87 \%$ to $95 \%)$ and temperature $\left(9.5\right.$ to $\left.10.7^{\circ} \mathrm{C}\right)$, during the seven days of evaluation.

\section{Variables evaluated}

\section{Fruit weight (g)}

It was obtained using a digital kitchen scale, with a capacity of $5 \mathrm{~kg}$. and sensitivity of $5 \mathrm{~g}$.

\section{Fruit color}

It was determined by means of a table of comparison of the states of maturation of the tomato based on Castro et al., (2009), in (figure 1 ) reference is made to the scale used.

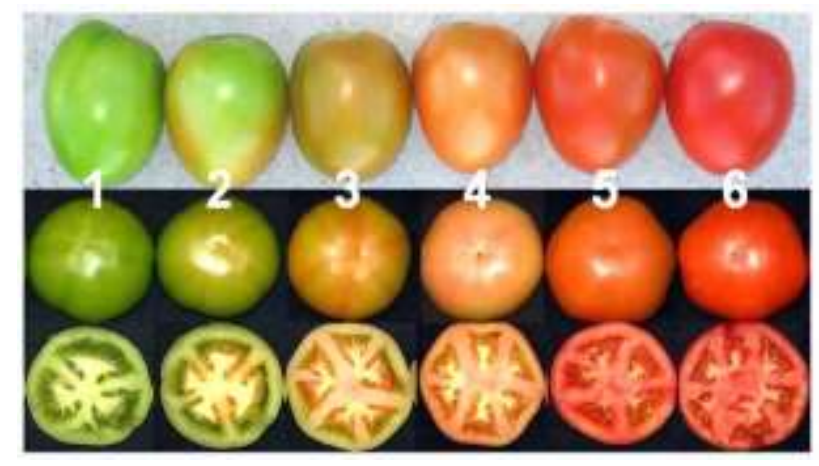

Figure 1 Tomato ripening states in relation to color:https://ricardodeleon1961.wordpress.com/2015/11/ 18/de-que-color-es-tu-mundo/

The treatments were selected in a range of 1-2 color (initial), for homogeneity. They were monitored for six days after selection, on the seventh day they were evaluated again (final). This parameter is important in the marketing of ToV tomatoes. In the region there are many marketers whose crops are exported to other countries, which have a record of the postharvest time is that it is seven days.
As it is a difficult variable to control in its traceability, in experience a good ToV tomato when offered to the customer must have a grade 4-5 on the maturation scale (figure 1), a scale below or above means the rejection of it, hence the importance of this variable.

\section{Statistic analysis}

Multiple pairwise comparisons, also called post hoc, were performed using the XLSTAT Software (2019). Using an LS means test, which allows us to compare the effects of the treatments with the variables evaluated and the application method as a whole.

\section{Results}

\section{Use of bioregulators}

From the statistical analysis, from the comparison of LS means for treatment-product, there was no difference between the various treatments of the products between them, but there is significant evidence with respect to the control (Figure 2). It can be mentioned that the use of the different bioregulators favor the variables evaluated, as is the case of the Martínez-Damian et al., (2019) study, the individual use of 2-chloroethyl phosphonic acid and iodine (I), increased significantly the weight and firmness of the fruits, respectively, with respect to the control, in the tomato crop.

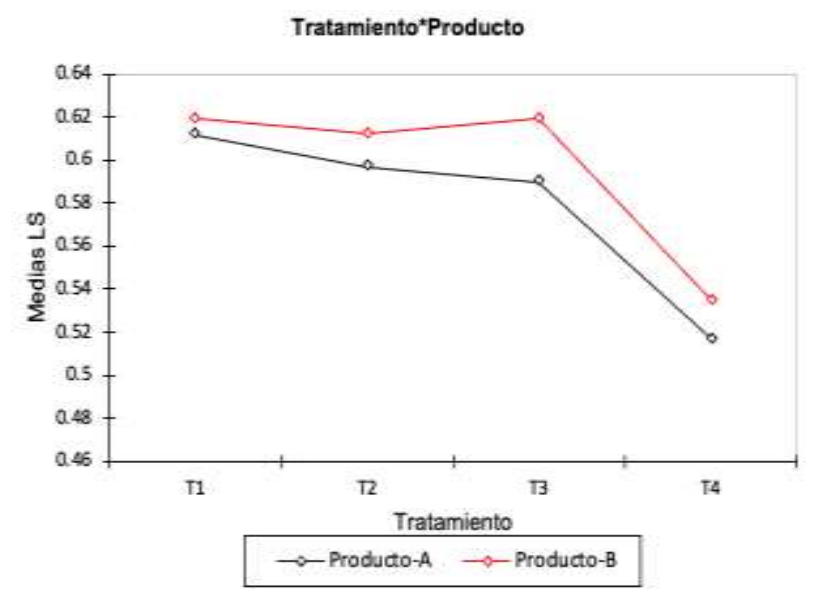

Figure 2 Analysis of LS means for treatment- product A) 2-chloroethyl phosphonic acid and B) K20

\section{Application technique}

From the analysis of multiple comparisons by pairs the statistical means LS for the application method factor, there are no statistical differences between the mopping and touch technique. 
It is concluded for this experiment the type of application does not favor the treatments (table 1). This indicates that the best application technique is the one that requires the least time resource. In some cases, the method of applying bioregulators by spraying shows a positive effect compared to the controls (Osuna-Enciso et al., 2019). so it can be an option and carry out an evaluation with this type of technique in tomato ToV.

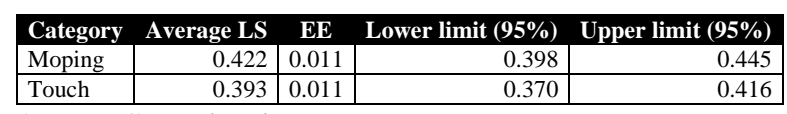

$* \mathrm{EE}=$ Standard error.

Table 1 LS means for the application method factor

\section{Fruit weight}

Among the weight of the fruits evaluated, there was no variation in loss or increase (Figure 3). In this sense, it cannot be compared with what happened in the work Martínez-Damian et al., (2019), in which the use of 2-chloroethyl phosphonic acid in sprayed plants had an increase of $62.5 \%$ compared to the control. On the other hand, the use of 2-chloroethyl phosphonic acid on tomato bunches increases the weight of $8 \%$ more compared to that which is not applied to it (Atta-Aly et al., 1999). Making it clear that the use of this bioregulator in other concentrations and phenological states in tomato favors a gain in fruit weight.

\section{Fruit color}

A difference is found in all treatments with respect to the control, based on the analysis of multiple comparison by pairs. The LS means of the treatments are summarized in (table 2) and for a better perception of these see (graph 3). What is confirmed visually and based on the reference of tomato maturation states, the existence of a difference in the use of bioregulators with respect to where it was not used. It should be noted that for this qualitative variable it is not controlled, since the color perspective depends on each evaluator; Therefore, it is useful to consider another way of measuring it to reduce the error in the operational part of an agricultural production unit, given the complexity of monitoring this type of important parameter in the commercialization of this crop.
It is known that the use of other bioregulators in tomato favors a homogeneous coloration. For example, the use of calcium prohexadione (Ca) (Martínez-Damian et al., 2019). However, an evaluation of Sodium Selate and Potassium Iodide in cherry tomatoes did not report color variations (Islam et al., 2018). On the other hand, the use of Selenium decreases the ripening rate by temporarily inhibiting the pathway of the ethylene biosintestines (Caffagni et al., 2012.), a phytohormone responsible for the ripening of the fruits and related to the color of the fruit..

\begin{tabular}{|l|l|l|l|l|}
\multicolumn{1}{|c|}{ Treatments } & Weight-Inc & \multicolumn{1}{c|}{ Weight-End } & \multicolumn{1}{c|}{ Col-Inc } & Col-FIN \\
\hline T1 & 0.402 & 0.399 & 0.509 & 0.833 \\
\hline T3 & 0.433 & 0.428 & 0.389 & 0.777 \\
\hline T2 & 0.412 & 0.406 & 0.388 & 0.777 \\
\hline T4 & 0.433 & 0.422 & 0.388 & 0.611 \\
\hline Pr> F (Model) & 0.4509 & 0.4570 & 0.0025 & $<0.0001$ \\
\hline Significant & No & No & No & No \\
\hline Pr> F (Treatment) & 0.4416 & 0.4910 & 0.0006 & $<0.0001$ \\
\hline Significant & No & No & No & Sí \\
\hline
\end{tabular}

Of the LS means of the treatments, treatment 4 (Control) shows a significant difference in the color variable.

Table 2 Summary of the LS means of the treatments

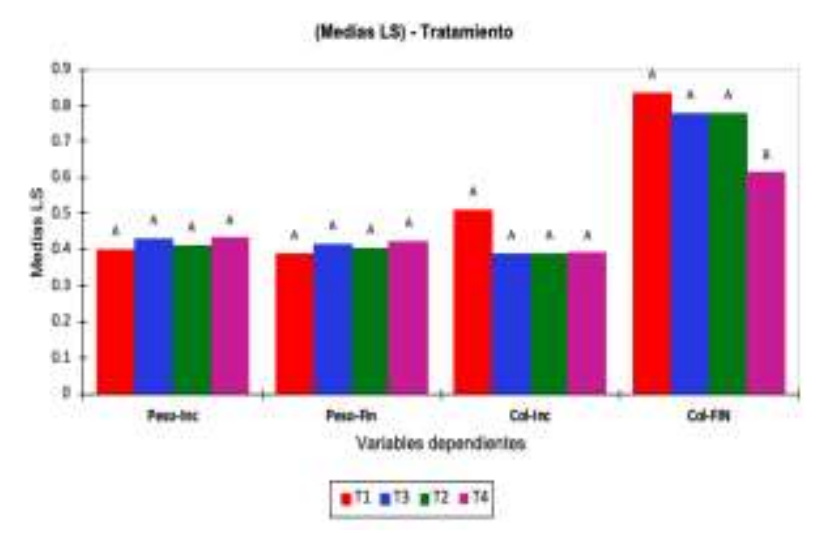

Figure 3 Graphic representation of the LS means of the experiment, weight Inc (initial), weight-end (Final), Colinc (initial) and col-FIN (final) of the treatments as a function of the set values. LS means with the same letters are not statistically different at a $95 \%$ confidence interval.

\section{Conclusion}

It will be possible to identify that the application techniques (mopping and touching) of the evaluated bioregulators, there is not a significant difference, so any technique can be used in the process of presenting ToV tomatoes. The bioregulators evaluated A) 2-chloroethyl phosphonic acid and B) K2O 20\%, had significant favorable differences for the fruit color variable, when compared with the control, but there was no effect on the fruit weight variable. 
Regarding the concentrations evaluated, no significant differences were found according to the analysis of multiple comparisons. Therefore, we can affirm that the use of these bioregulators in the concentrations evaluated favors the uniformity of the color of the fruit since at seven days of evaluation the ToV tomatoes treated with the bioregulators were on average in the five state of maturity, which is what suitable for the international market.

\section{References}

Atta-Aly, M. A., Riad, G. S., Lacheene, Z. S., \& Beltagy, A. S. (1999). Early application of ethrel extends tomato fruit cell division and increases fruit size and yield with ripening delay. Journal of Plant Growth Regulation, 18(1), 15-24. doi: 10.1007/PL00007041

Castro, K., Restrepo, M.L., Taborda, G., \& Quintero, G.A. (2009). Intensidad de los sabores básicos del tomate (Lycopersicon esculentum) en seis estados de madurez. Biotecnología en el Sector Agropecuario y Agroindustrial, 7, 23-28.

Chandrika G U, E Jansz, S Nalinie, N Warnasuriya (2003) Carotenoids in yellow- and red-fleshed papaya (Carica papaya L). J. Sci. Food Agric. 83:1279-1282.

Crisosto, C. H., Bremer, V., Norton, M., Ferguson, L., \& Einhorn, T. (2010). Preharvest ethephon eliminates first crop figs. HortTechnology, 20(1), 173-178.

Cuesta, Graciela y Mondaca, Eduardo (2014). Efecto de un biorregulador a base de auxinas sobre el crecimiento de plantines de tomate. Revista chapingo serie horticultura, 20 (2), 215222.

INTAGRI. 2017. Tipos y Especialidades de Tomate. Serie Hortalizas Núm. 13. Artículos Técnicos de INTAGRI. México. 4 p.

Leyva Trinidad, Doris Arianna, \& Pérez Vázquez, Arturo. (2015). Pérdida de las raíces culinarias por la transformación en la cultura alimentaria. Revista mexicana de ciencias agrícolas, 6(4), 867-881.

Luna-Guevara, M. L., \& Delgado-Alvarado, A. (2014). Importancia, contribución y estabilidad de antioxidantes en frutos y productos de tomate (Solanum lycopersicum L.). Avances en Investigación Agropecuaria, 18(1),51-66.[
Martínez-Damián, María Teresa, CanoHernández, Rene, Moreno-Pérez, Esaú del Carmen, Sánchez-del Castillo, Felipe, \& CruzÁlvarez, Oscar. (2019). Efecto de biorreguladores del crecimiento en precosecha sobre la calidad fisicoquímica de tomate saladette. Revista Chapingo. Serie horticultura, 25(1), 29-43.

Martínez Díaz, A. L. (2017). Evaluación de tres niveles de fertilización foliar con Boro y Potasio en dos distanciamientos de siembra en el cultivo de frejol (Phaseolus vulgaris) en la zona de Babahoyo (Bachelor's thesis, Babahoyo: UTB, 2017).

Navarro-González, Inmaculada, \& Periago, María Jesús. (2016). El tomate, ¿alimento saludable y/o funcional?. Revista Española de Nutrición Humana y Dietética, 20(4), 323-335. https://dx.doi.org/10.14306/renhyd.20.4.208

Osuna-Enciso, Tomás, Chavarín-Navarro, Zulema M., Carrillo-Fasio, José A., ValdezTorres, José B., Basilio-Heredia, José, BáezSañudo, Manuel A., Hernández-Verdugo, Sergio, \& Osuna-Rodríguez, José M.. (2019). Efecto de aspersiones de biorreguladores en precosecha sobre el crecimiento y maduración del mango keitt. Revista fitotecnia mexicana, 42(3), 259-268.

Palomo, Iván; Moore-Carrasco, Rodrigo; Carrasco, Gilda; Villalobos, Pablo; Gusmán, Luis .El consumo de tomates previene el desarrollo de Enfermedades Cardiovasculares y Cáncer: Antecedentes epidemiológicos y mecanismos de acción. IDESIA (Chile). 28 (3), 121-129.

Ramírez, H., Leza, P. C., Rivera, C. E., Amado, C., Benavides, A., Herrera, B., Martínez, A., \& Méndez, O. (2012). Prohexadione-Ca reduces plant height, improves yield and fruit quality on solanaceous crops. Acta Horticulturae, 936, 457-462.

XLSTAT. (2019) Software estadístico para Excel. Paris: Addinsoft. Available in: https://www.xlstat.com/es/

CALDERÓN-RUIZ, Alberto, MARTÍNEZ-CAMACHO, Adriana Paola, ESPINOZA-ZAMORA, Jesús and RIVERA-ARREDONDO, Marisa. Use bioregulators in cluster ToV (Salanum lycopersicum L.). Journal of Natural and Agricultural Sciences. 2020 